Sumber Daya Manusia Dalam ... (Anisa Sri Restanti)

\title{
SUMBER DAYA MANUSIA DALAM PENGEMBANGAN PERPUSTAKAAN : Studi Pemikiran Lasa Hs.
}

\author{
Anisa Sri Restanti \\ Pustakawan UPT Perpustakaan Universitas Jenderal Soedirman \\ anisasrirestanti@gmail.com
}

Dewasa ini perpustakaan telah mengalami kemajuan yang cukup pesat. Perpustakaan bukan sekedar tempat mengelola buku dan terbitan lain, namun juga mengelola sumber informasi dengan memanfaatkan teknologi informasi. Perkembangan pemahaman khususnya manajemen perpustakaan di Indonesia tentu saja tidak terlepas dari peran aktif para pustakawan ataupun pemerhati dunia kepustakawanan. Lasa Hs merupakan salah satu pustakawan yang telah banyak melontarkan pemikiran kepustakawanan dalam bentuk buku, kamus, ensiklopedi, makalah, artikel, dan lainnya. Dengan produktivitas itu, beliau mampu menunjukkan bahwa pustakawan mampu berprestasi sejajar dengan jabatan fungsional lain.Dengan prestasi ini beliau mampu menduduki jabatan fungsional pustakawan utama, golongan IV/e dan purna tugas pada umur 65 tahun dengan angka kredit/prestasi nyata. Tujuan penelitian ini, untuk mengetahui pemikiran Lasa Hs. mengenai manajemen sumber daya manusia dalam kepustakawanan. Penelitian ini merupakan penelitian dokumen. Metode pengumpulan data menggunakan studi literatur dan wawancara. Hasil penelitian menunjukkan bahwa; (1) pemikiran Lasa Hs. menempatkan sumber daya manusia merupakan pilar utama dalam kegiatan perpustakaan; (2) fungsi manajemen sumber daya manusia menurut Lasa Hs. mencakup penyediaan staf, pengembangan sumber daya manusia, kompensasi, keselamatan dan kesehatan; (3) Lasa Hs. mempunyai pemikiran ke depan mengenai sumber daya manusia perpustakaan. Hal ini terlihat dari adanya kompetensi khusus yang harus dimiliki oleh pustakawan. Dari hasil tersebut dapat disimpulkan bahwa peningkatan sumber daya manusia perlu mendapat perhatian utama karena sumber daya ini merupakan sumber daya bergerak, sedangkan sumber daya lain merupakan benda mati. Oleh karena itu, sumber daya manusia ini dapat dikembangkan dan ditingkatkan kemampuannya, yang hasilnya diharapkan mampu meningkatkan produktivitas dan kinerja perpustakaan. Pemikiran tentang manajemen sumber daya manusia perpustakaan ini terus dikembangkan melalui berbagai artikel, makalah, dan penulisan buku Manajemen Sumber Daya Manusia.

Kata kunci: Manajemen sumber daya manusia, Pustakawan, Lasa Hs.

\section{Pendahuluan}

Perpustakaan merupakan istilah yang tentu saja tidak asing lagi bagi masyarakat. Perpustakaan identik dengan tempat penyimpanan buku-buku. Pemahaman tersebut tidak dapat disalahkan sepenuhnya. Hal ini terjadi karena ketidaktahuan oleh sebagian masyarakat tentang makna sebuah perpustakaan. Satu hal yang kita ingat seperti yang disampaikan Sulistyo-Basuki (1991:3) menyatakan bahwa perpustakaan adalah sebuah ruangan, bagian sebuah gedung, ataupun gedung itu sendiri yang digunakan untuk menyimpan buku dan terbitan lainnya menurut tata susunan tertentu untuk digunakan pembaca, bukan untuk dijual.
Dalam pengertian ini, perpustakaan diidentikkan dengan ruangan, koleksi, penyimpanan, dan pemanfaatan. Selain itu yang perlu digaris bawahi adalah dalam menyimpan buku dan terbitan lainnya menurut tata susunan tertentu hal ini dapat dimaknai bahwa dalam pengelolaan perpustakaan tidak sekedar disimpan dan dimanfaatkan.

Tidak ada yang abadi dalam dunia ini kecuali perubahan itu sendiri. Pepatah ini menyiratkan bahwa hidup ini dinamis dan inovatif, artinya selalu mengalami perubahan dari waktu ke waktu. Begitu juga dalam dunia kepustakawanan. Dewasa ini perpustakaan telah mengalami kemajuan yang cukup pesat. Perpustakaan bukan sekedar tempat mengelola 
buku dan terbitan lain, namun juga mengelola sumber informasi dengan memanfaatkan teknologi informasi. Dalam hal ini Lasa Hs (2008) menyatakan bahwa perpustakaan merupakan sistem informasi yang didalamnya terdapat aktivitas pengumpulan, pengolahan, pengawetan, pelestarian dan penyajian serta penyebaran informasi. Informasi meliputi produk intelektual dan artistik manusia. Dalam melaksanakan aktivitas tersebut diperlukan ilmu pengetahuan yang diperoleh melalui pendidikan formal atau nonformal di bidang perpustakaan, dokumentasi dan informasi. Dalam pengertian ini perpustakaan dititik beratkan pada sistem dan informasinya, meskipun juga memerlukan tempat. Artinya sistem kepustakawanan harus selalu berubah dan informasi kenyataan juga selalu berkembang. Perubahan ini memerlukan sumber daya manusia yang akan menggerakkan perubahan itu. Kalau sumber daya manusia sendiri tidak berubah (pendidikan, jumlah, kompetensi, dan cara berpikir dan berperilaku) maka sangat mungkin perpustakaan juga sulit berubah alias stagnan.

Perpustakaan ditinjau dari segi perkembangan budaya, dapat merupakan agen perubahan (agent of change). Hal itu dapat dimungkinkan dan dapat dimengerti, karena di perpustakaan terkumpul dan tersimpan banyak sekali informasi, ilmu pengetahuan, sejarah, filsafat dan penemuan serta pemikiran dari masa lalu (Sutarno, 2006). Dari berbagai pengertian tersebut dapat dipahami bahwa pengertian perpustakaan memiliki unsur yang sama yakni kegiatan menghimpun, mengolah, dan memberdayakannya untuk dimanfaatkan oleh masyarakat. Pengelolaan informasi di perpustakaan tersebut akan lebih berdaya guna dan berhasil guna mana kala para pelakunya disamping menguasai ilmu perpustakaan, juga mengerti, memahami, dan mampu menerapkan manajemen perpustakaan (Sutarno, 2006).

Perkembangan pemahaman mengenai manajemen perpustakaan di Indonesia, tentu saja tidak terlepas dari peran aktif para pustakawan ataupun pemerhati dunia kepustakawanan. Para tokoh tersebut telah menyumbangkan pemikirannya sehingga wawasan masyarakat lebih terbuka. Lasa Hs. merupakan salah satu pustakawan yang termasuk produktif telah menulis lebih dari 200 artikel dan 200 judul lebih makalah hasil pemikiran beliau telah dimuat di media cetak Yogyakara, Surakarta, Semarang, Surabaya, Bogor, Jakarta, Riau. Selain itu, juga telah menulis lebih dari 45 judul buku bidang kepustakawanan, penulisan, agama Islam, dan Kemuhammadiyahan yang telah diterbitkan oleh 15 penerbit.

Berdasarkan latar belakang tersebut, penulis tertarik untuk mengetahui bagaimana pemikiran Lasa Hs. mengenai manajemen perpustakaan khususnya tentang manajemen sumber daya manusia dalam kepustakawanan. Adapun tujuan penelitian ini, untuk mengetahui pemikiran Lasa Hs. mengenai manajemen sumber daya manusia dalam kepustakawanan.

\section{Manajemen Sumber Daya Manusia}

Manajemen merupakan bagian paling penting dari ilmu administrasi, yaitu merupakan inti administrasi. Secara sederhana administrasi itu mengandung pengertian sebagai "suatu proses penyelenggaraan kegiatan yang dilakukan oleh dua orang atau lebih untuk mencapai tujuan yang telah ditentukan". Sementara manajemen merupakan pengendalian dan pemanfaatan semua faktor dan sumber daya (Sutarno, 2006). Pengertian manajemen telah banyak dibahas para ahli. Pendapat James F. Stoner (1982), yang dikutip oleh Handoko (1993:8) dalam Lasa Hs (2009: 199) menyatakan bahwa manajemen merupakan proses perencanaan, pengorganisasian, pengarahan, dan pengawasan para anggota dan sumber daya lainnya untuk mencapai tujuan organisasi yang telah ditetapkan. Di sini James F. Stoner menekankan bahwa manajemen bertitik berat pada proses dan sistem. Oleh karena itu, apabila dalam sistem dan proses perencanaan, pengorganisasian, pengarahan, penganggaran, dan pengawasan itu kurang baik, maka proses manajemen itu secara keseluruhan juga kurang baik.

Sementara itu, O.R. Terry, yang dikutip oleh Hadi (1990:2) dalam Lasa Hs (2008), menyatakan bahwa manajemen adalah usaha pencapaian tujuan yang telah ditetapkan dengan menggunakan keahlian orang lain. Dalam hal ini, Terry tidak menjelaskan unsur-unsur apa saja yang diperlukan manajemen agar dalam proses 
pencapaian tujuan berjalan lancar. Selanjutnya, Qalyubi (2003) mengutip pengertian manajemen dalam Ensiklopedi Nasional Indonesia vol.16 disebutkan bahwa manajemen merupakan proses perencanaan, pengorganisasian, dan pengawasan sumber daya manusia dan sumber-sumber lain untuk mencapai tujuan ataupun sasaran secara efektif dan efisien. Dalam pengertian ini, manajemen dikatakan baik, apabila suatu organisasi/ lembaga memiliki tujuan dan sasaran yang jelas serta diketahui oleh semua yang terlibat dengan kegiatannya. Untuk itu disusun langkah-langkah kegiatan untuk mencapai tujuan dengan memanfaatkan segala sumber (manusia, dana, sarana, kesempatan, sumber alam, dan lainnya) secara optimal agar efektif dan efisien. Kegiatan dan elemenelemen yang mendukung perlu diorganisasi agar tidak tumpang tindih satu dengan yang lain. Kemudian, dalam pelaksanaannya perlu dilakukan kepemimpinan dan pengawasan.

Dari penjelasan tersebut, dapat dipahami bahwa pendefinisian manajemen terdapat dua kelompok. Kelompok pertama pendefinisian manajemen yang menekankan pada kegiatan manajemen. Para ahli yang masuk kelompok ini adalah Heinz Weinrich dan Harorld Kosutz yang dalam bukunya Management: A global perspective menyatakan bahwa management is the process designing and maintaining environment in which individuals, working together in groups, efficiency accomplish selected aims. Pendapat ini didukung oleh Paul Hersey, Kenneth H. Blancard, Andrew N. Sziloggi, dan Bernard Keys. Kelompok kedua, pendefinisian manajemen yang menekankan pada fungsi manajemen, antara lain adalah George Terry yang menyatakan bahwa management is a distict process consisting of planning, organizing, actuating, and controlling, performed to determine and accomplish stated objectives by the use of human beings and other resources. Pendapat ini juga didukung oleh Don Heleroegel, James A.I. Stones, dan Donald . Mosky (Qalyubi, 2003).

Dalam manajemen, manusia merupakan salah satu sumber daya yang dapat berfungsi untuk mencapai tujuan. Hal ini seperti yang dinyatakan Dessler (1997), bahwa manajemen sumber daya manusia (SDM) merupakan kebijakan dan praktik yang dibutuhkan seseorang untuk menjalankan aspek "orang" atau sumber daya manusia dari posisi seorang manajemen, meliputi perekrutan, penyaringan, pelatihan, pengimbalan, dan penilaian. Oleh karena itu, SDM memainkan peran penting dalam perusahaan-perusahaan jasa. Sebagaimana dikemukakan wakil presiden dari sumber daya manusia pada Toyota Motor Manufacturing di Georgetown, Kentucy dalam Dessler (1997):

\begin{abstract}
"orang berada dibalik sukses. Mesin tidak memiliki gagasan baru, memecahkan masalah, atau menangkap peluang. Hanya orang yang terlibat dan berfikir dapat melakukan perbedaan....setiap pabrik mobil di A.S pada dasarnya memiliki mesin yang sama. Tetapi bagaimana orang dimanfaatkan dan dilibatkan itu sangat berbeda dari perusahaan ke perusahaan. Angkatan kerja memberikan kepada perusahaan mana saja sisi kompetitif yang sejati."
\end{abstract}

Menurut Mondy (2008), manajemen sumber daya manusia merupakan pemanfaatan para individu untuk mencapai tujuan-tujuan organisasi. Selanjutnya, perpustakaan sebagai institusi dengan produk "jasa" akan memiliki kinerja yang baik apabila ditunjang dengan manajemen sumber daya manusia yang memadai. Berkenaan dengan hal ini terdapat empat kompetensi yang harus dimiliki oleh SDM untuk mengelola perpustakaan yaitu philosophical competencies, technical competences, professional competencies, dan personal competencies (The Tampa Bay Library Concortium, 2002 dalam Chon, 2005).

\section{Fungsi Manajemen Sumber Daya Manusia}

Setiap individu atau orang-orang yang terlibat dalam manajemen sumber daya manusia mengembangkan dan bekerja melalui sistem manajemen sumber daya manusia yang terintegrasi. Fungsi-fungsi manajemen sumber daya manusia, meliputi:

a. Penyediaan staf, merupakan proses yang menjamin suatu organisasi untuk selalu memiliki jumlah karyawan yang tepat dengan keahlian-keahlian yang memadai dalam pekerjaan-pekerjaan yang tepat untuk mencapai tujuan organisasi. Penyediaan staf mencakup analisis pekerjaan, perencanaan 
sumber daya manusia, perekrutan, dan seleksi.

b. Pengembangan sumber daya manusia, merupakan pendekatan formal yang digunakan oleh organisasi untuk memastikan bahwa orang-orang dengan kualifikasi dan pengalaman-pengalaman yang memadai tersedia ketika dibutuhkan. Fungsi ini meliputi pelatihan dan pengembangan dan juga aktivitas-aktivitas perencanaan dan pengembangan karier individu, pengembangan organisasi, serta manajemen dan penilaian kinerja.

c. Kompensasi, mencakup semua imbalan total (kompensasi finansial langsung, kompensasi finansial tidak langsung/ tunjangan, kompensasi nonfinansial) yang diberikan kepada para karyawan sebagai timbal balik untuk jasa mereka.

d. Keselamatan dan kesehatan, kedua aspek dari pekerjaan tersebut penting karena para karyawan yang bekerja dalam lingkungan yang aman dan menikmati kesehatan yang baik akan cenderung lebih produktif dan memberikan manfaat jangka panjang bagi organisasi.

e. Hubungan kekaryawanan dan perburuhan, suatu perusahaan dituntut oleh hukum untuk mengakui serikat pekerja dan berunding dengannya dengan iktikad baik jika para karyawan perusahaan yang bersangkutan menginginkan serikat pekerja mewakili mereka (Mondy, 2008).

\section{Metode penelitian}

\section{Desain penelitian}

Penelitian ini merupakan penelitian dokumen (historical research) yakni penelitian terhadap literatur yang selama ini terkumpul di perpustakaan. Menurut Hillway dalam Hartinah (2013) salah satu kelompok penelitian terhadap dokumen penelitian adalah penelitian biografi. Penelitian ini dilakukan terhadap literatur yang relevan dengan permasalahan yang dikaji dan dapat menunjang pemecahan pokok-pokok masalah.

\section{Metode pengumpulan data}

Metode pengumpulan data yang digunakan adalah: a. Dokumen

Dokumen digunakan sebagai sumber
data dimanfaatkan untuk menguji, menafsirkan, bahkan untuk meramalkan (Moleong, 2007). Peneliti menelusuri dan mengkaji literatur primer berupa sumber data utama dari hasil karya tokoh yang diteliti yakni Lasa Hs., dan juga dokumen hasil karya selain tokoh yang berkaitan dengan pokok bahasan penelitian.

b. Wawancara

Peneliti melakukan wawancara
tidak terstruktur kepada tokoh yang
diteliti. Wawancara ini digunakan untuk
menemukan informasi yang bukan baku,
hasil wawancara ini menekankan penafsiran
kembali, pendekatan baru, pandangan ahli,
atau perspektif tunggal. Pelaksanaan tanya-
jawab mengalir seperti dalam percakapan
sehari-hari (Moleong, 2007).

\section{Teknik pengolahan data}

Dalam pengolahan data, peneliti melakukan:

a. Mengumpulkan data dan memeriksanya terutama dari segi kelengkapan, kejelasan, keakuratan dan kesesuaian dengan bahasan penelitian.

b. Mengklasifikasi dan mensistemasi data dalam paparan yang direncanakan.

c. Melakukan analisa lebih lanjut terhadap data yang telah diklasifikasikan tersebut sehingga diperoleh kesimpulan.

d. Selanjutnya menggunakan teknik triangulation, yaitu dengan mengumpulkan berbagai informasi tentang berbagai hal dari berbagai sudut pandang dan memeriksa pandangan seseorang dengan hasil penelitian, atau sebaliknya meminta persetujuan (konfirmasi) hasil penelitian kepada orang yang ditelitinya (Pendit, 2003).

\section{Pembahasan}

\section{Riwayat Hidup Lasa Harsana}

\section{Kehidupan Awal dan Pendidikan Dasar}

Lasa Hs, dilahirkan di Boyolali pada 1 Januari 1948. Sebagai anak pertama dari tiga bersaudara. Pendidikan awal beliau dapatkan 
Sumber Daya Manusia Dalam ... (Anisa Sri Restanti)

dari kedua orang tuanya, dilanjutkan ke Sekolah Rakyat Islam Mambaul 'Ulum di Boyolali. Selanjutnya melanjutkan sekolah ke Madrasah Tsanawiyah Al-Islam di Boyolali, yang kemudian meneruskan sekolah Madrasah 'Aliyah Al-Islam di Surakarta. Selama mengikuti pendidikan di Al-Islam ini, beliau juga menjadi santri Pondok Pesantren Nirbitan Surakarta. Pendidikan berkarakter Islam dan dengan menjaga konsistensi, hingga saat ini beliau bersosok religius.

Pendidikan kesarjanaannya ditempuh pada program studi Bahasa Arab Fakultas Sastra dan Kebudayaan (sekarang Fakultas IImu Budaya) Universitas Gadjah Mada (UGM) Yogyakarta tahun 1979. Kemudian beliau memperoleh pendidikan dan latihan perpustakaan di UGM tahun 1973, penataran Perpustakaan Kopertis wilayah V DIY, Program Sertifikat Ahli Perpustakaan Fakultas Sastra UI Jakarta, magang Pengelolaan Terbitan Berkala di UPT Perpustakaan ITB Bandung, Penataran Tim Penilai Angka Kredit Pustakawan Tk. Nasional di Perpusnas RI Jakarta. Sedangkan gelar Magister Sains Manajemen Perpustakaan dari Pascasarjana UGM tahun 2002.

\section{Pengalaman dan Basis Pemikiran}

Profesi sebagai pustakawan ditekuni sejak tahun 1972 dan dikukuhkan sebagai pustakawan utama pada tahun 2007 di UPT Perpustakaan UGM Bulaksumur Yogyakarta. Beliau pernah bekerja di Perpustakaan Fakultas Teknologi Pertanian UGM (1972-Oktober 2006). Perpustakaan Akademi Arsitektur YKPN (19751980), Perpustakaan Fakultas Sastra dan Kebudayaan UGM, Perpustakaan Fakultas Kehutanan UGM, dan Perpustakaan Institut Pertanian Yogyakarta (1983-2008). la pernah menjabat sebagai Kepala Bidang Pelayanan Perpustakaan UGM (November 2006Januari 2012). Kini beliau mendapat amanah sebagai Kepala Perpustakaan Universitas Muhammadiyah Yogyakarta (UMY).

Selain pustakawan, beliau juga pernah berprofesi sebagai guru SMP Muhammadiyah Depok Sleman Yogyakarta (1972-1973), dosen Agama Islam di Akademi Manajemen Putra Jaya (1985-1990), dosen Agama Islam di
Institut Pertanian (1983-2006), dosen D3 IImu Perpustakaan FISIPOL UGM, dosen D3 dan S1 IImu Perpustakaan Fakultas Adab UIN SUKA (1999-sekarang). Beliau pernah menjadi dosen Manajelen IImu Perpustakaan Pascasarjana UGM, dan Kajian IImu Perpustakaan IIS Pascasarjana UIN Sunan Kalijaga Yogyakarta (2009-2011). Dosen Agama Islam Diploma Agribisnis Fakultas Teknologi Pertanian UGM (2002-2011), dan sampai kini masih menjadi Tutor mata kuliah IImu Perpustakaan FISIPOL Universitas Terbuka Surakarta dan DIY.

Dalam organisasi profesi, beliau pernah menjadi anggota pengurus IPI DIY (19901993), anggota pengurus Majelis Pustaka dan Informasi PP Muhamadiyah (1995-2000), Wakil Ketua Forum Perpustakaan Perguruan Tinggi Indonesia/FPPTI DIY (2003-2006), anggota Pengurus Lembaga Pustaka dan Informasi PP Muhammadiyah (2005-2010), Wakil Ketua Lembaga Pustaka dan Informasi PDM kota Yogyakarta (2005-2010), anggota Pengurus Majelis Pustaka \& Informasi PP Muhamadiyah (2011-2015), pendiri Himpunan Pengelola Perpustakaan Sekolah Muhamadiyah Kota Yogyakarta, dan Ketua Forum Silaturahim Perpustakaan Perguruan Tinggi Muhammadiyah (2012-2016). Kegiatan itu masih ditambah sebagai anggota Pengurus Dewan Perpustakaan DIY, dan asesor. Juga sebagai anggota Tim Penilai Angka Kredit Pusakawan UII, dan pernah menjadi anggota Tim Penilai Angka Kredit Pustakawan UGM maupun UPN, serta pernah menjadi anggota Tim Perumus Standar Nasional Perpustakaan Sekolah dan Perguruan Tinggi Perpustakaan Nasional RI, serta sebagai narasumber berbagai seminar dan juri lomba kepustakawanan DIY dan Jawa Tengah.

Di bidang redaksional, pernah menjadi redaksi buletin Al Fata, Al Fikr, Agritech (Fakultas Teknologi Pertanian UGM), Media informasi (Perpustakaan Pusat UGM), Berkala IImu Perpustakaan dan Informasi (Perpustakaan Pusat UGM), Palmisest (Jurusan IImu Perpustakaan FISIPOL UNAIR Surabaya), Mentari (PDM kota Yogyakarta, dan reviewer jurnal UNILIB (Direktorat Perpustakaan UII Yogyakarta). 


\section{Filsafat Hidup}

Membaca tanpa menulis ibarat orang pincang berjalan, membaca saja tidak cukup harus diseimbangkan dengan menulis. Menulis sama saja menuangkan ide yang didapat dari membaca. Menulis tanpa membaca ibarat orang buta berjalan, untuk bisa menulis harus banyak membaca. Dengan membaca akan mendapatkan banyak ide untuk menulis. Sehingga beliau ingin menjadi orang yang "awas" dan bisa berjalan sehingga bisa bergerak cepat. Ide kecil akan jadi apa-apa bila diperjuangkan namun ide besar tidak akan jadi apa-apa kalau hanya disimpan di otak.

Membaca dan menulis merupakan dua kegiatan yang saling terkait ibarat dua keping mata uang sebagai media pengembangan pemikiran dan pengabadian ilmu dan nama. Maka beliau selalu berpesan dalam bentuk tulisan pada buku-bukunya atau pembatas baca dengan tulisan "Jangan Tidur Sebelum Membaca. Jangan Mati Sebelum Menulis".

Tulis menulis merupakan penyebaran ide, pemikiran, ilmu, dan informasi yang bisa tembus dimensi waktu, geografis, ras, dan agama. Maka ilmuwan dan profesional (termasuk pustakawan) yang tidak menulis ibarat burung bersayap satu yang hanya bisa hinggap dari ranting satu ke ranting lain atau dari satu pohon ke pohon lain. Hal ini tentunya berbeda dengan ilmuwan dan profesional yang memiliki tulisan ibarat burung bersayap dua yang mampu terbang lintas benua.

\section{Hasil Karya}

Lasa Hs. mulai aktif menulis sejak remaja. Pada awalnya beliau banyak menulis dengan topik keagamaan. Seiring perjalanan waktu beliau konsen pada empat topik penulisan yaitu religi (agama), kepustakawanan, penulisan, dan manajemen. Sampai saat ini telah lebih dari dua ratus artikel hasil pemikiran beliau dimuat di media cetak Yogyakarta, Surakarta, Semarang, Surabaya, Bogor, Jakarta, dan Riau. Beberapa artikel tersebut antara lain Peran Informasi IPTEK Dalam Alih Informasi (Media Informasi, IV (2) Juni 1997), Celah-Celah Tulisan Pustakawan (Media Pustakawan, IV (3) September 1997), Pengembangan Karir dan Profesi Pustakawan (Buletin Perpustakaan, (2) April 1997), Dibalik
Angka Kredit dan Pengumpulannya (Wahana Informasi Perpusdokinfo, Vol. 18, Ed. Juli 2014).

Adapun karya tulis dalam bentuk buku sebanyak 45 judul, diterbitkan oleh 15 penerbit dan ada masih terdapat beberapa judul dalam bentuk draff. Adapun judul buku hasil pemikiran beliau antara lain Ensiklopedi Muhammadiyah (karya bersama, Rajagrafindo, 2005), Kamus Istilah Perpustakaan (Kanisius, 1990, 1993, Gadjah Mada University Press, 1998), Membina Perpustakaan Sekolah Islam dan Madrasah (dicetak 10.000 eks. Oleh Adicita Karya Nusa, 2004), Manajemen Perpustakaan (Gama Media, 2005), Petunjuk Pengelolaan Perpustakaan Masjid (Gadjah Mada University Press, 1998), Manajemen Perpustakaan Sekolah (Pinus, 2007), Manajemen Perpustakaan Sekolah/ Madrasah (Ombak, 2013), Seratus Tokoh Muhammadiyah (karya bersama, MPI PP Muhammadiyah, 2015), dan Manajemen dan Standardisasi Perpustakaan Sekolah/ Madrasah Muhammadiyah (MPI PDM Kota Yogyakarta, 2015). Adapun naskah buku yang dalam penyelesaian antara lain Kamus Kepustakawanan Indonesia (ditulis 352 halaman satu spasi) dan Manajemen Sumber Daya Manusia Perpustakaan (172 halaman satu spasi).

\section{Kritikan Penulisan}

Menulis pada dasarnya adalah melontarkan ide secara luas dan tidak perlu minta ijin kepada siapapun termasuk kepada atasan langsung, apalagi bila atasan langsung itu tidak pernah menulis dan tidak mengetahui seluk beluk penulisan. Disadarinya bahwa ide yang dilontarkan pasti menimbulkan pro dan kontra. Hal ini merupakan suatu kewajaran bahwa dalam kehidupan ini tentu ada perbedaan pendapat, selera, dan keinginan.

Namun demikian, mengingat bahwa tulisan merupakan media pertukaran informasi keilmuan maka sewajarnya apabila penolakan ide itu juga dalam bentuk tulisan. Kalau yang ditolak itu tulisan berbentuk buku, semestinya ketidaksetujuan itu juga ditulis dalam bentuk buku. Demikian pula dengan artikel yang tentunya juga ditolak melalui artikel atau minimal dalam bentuk resensi.

Dengan cara seperti itu akan lebih fair dan menunjukkan sikap ilmiah sebagai seorang 
akademisi atau profesional. Melalui buku dan artikel penolakan ide itu yang ditulis secara ilmiah dan dengan metode penulisan ilmiah itu, pembaca akan mengetahui dan memilih ide mana yang baik, rasional, ilmiah, dan dapat dipertanggung jawabkan.

Memangsebagianbesarpenulismerasakan dan mendengar orang lain berkomentar tentang karya-karya mereka. Para penulis terkenalpun sering mendapatkan cemoohan "kalau cuma gitu, kalau saya mau menulis pasti lebih baik". Namun realita menunjukkan bahwa mereka yang berkomentar itu tidak pernah menulis bahkan sampai purna tugaspun tak secuwilpun artikel yang muncul di media cetak tingkat lembaga apalagi tingkat nasional.

\section{Pemikiran Lasa Hs tentang Manajemen Perpustakaan dan Sumber Daya Manusia}

Perpustakaan sebagai unit informasi akan memiliki kinerja yang baik apabila dikelola dengan manajemen yang memadai. Dengan adanya manajemen yang baik, semua aktivitas perpustakaan akan mengarah pada upaya pencapaian tujuan kegiatan perpustakaan akan mencapai tujuan yang telah ditetapkan. Dalam mendefinisikan manajemen perpustakaan Lasa Hs (2013) menyatakan bahwa manajemen perpustakaan adalah segala usaha pencapaian tujuan perpustakaan dengan memanfaatkan sumber daya manusia, informasi, ilmu pengetahuan, sistem, sumber dana, sarana prasarana, dan sumber daya lain dengan tetap memperhatikan fungsi, peran, dan keahlian. Untuk mencapai tujuan perpustakaan diperlukan sumber daya manusia dan nonmanusia antara lain berupa sumber dana, teknik, fisik, alam, informasi, ide, peraturan, maupun teknologi informasi. Sumber daya ini dikelola melalui proses manajemen yang meliputi perencanaan, pengorganisasian, kepemimpinan, dan pengawasan yang menghasilkan produk (barang/ jasa).

Dari definisi tersebut terlihat Lasa Hs menekankan pada kegiatan manajemen. Pendapat ini didukung oleh Sutarno NS (2006) bahwa manajemen perpustakaan merupakan salah satu kajian tentang apa dan bagaimana cara-cara yang dapat dilakukan, baik melalui teori maupun praktik agar perpustakaan dapat dikelola dengan berdaya guna dan berhasil guna, sehingga keberadaannya di tengah-tengah masyarakat mampu menyeleksi, menghimpun, mengolah, memelihara sumber informasi dan memberdayakan dengan memberikan layanan, serta nilai tambah bagi mereka yang membutuhkannya.

Sementara itu, Abdul Rahman Saleh sedikit berbeda dengan pemikiran tersebut, dalam pemikirannya menitik beratkan pada fungsi manajemen. Pengertian manajemen dalam Saleh (2011: 1.31) disebutkan bahwa manajemen diartikan sebagai pengendalian dan pemanfaatan semua faktor dan sumber daya yang menurut suatu perencanaan diperlukan untuk mencapai atau menyelesaikan suatu tujuan tertentu.

Selanjutnya menurut Lasa Hs. maju mundurnya suatu lembaga sangat dipengaruhi oleh sistem manajemen. Peningkatan sumber daya manusia (SDM) perlu mendapat perhatian utama karena sumber daya ini merupakan sumber bergerak, sedangkan sumber daya lain merupakan benda mati. Oleh karena itu, sumber daya manusia ini dapat dikembangkan dan ditingkatkan kemampuannya, yang hasilnya diharapkan mampu meningkatkan produktivitas dan kinerja perpustakaan. Seluruh SDM yang dimiliki perpustakaan perlu diatur sedemikian rupa, dalam hal ini di sebut "Manajemen Sumber Daya Manusia".

ManajemenSumberDayaManusiamenurut Dessler (1997:2) adalah kebijakan dan praktik yang dibutuhkan seseorang untuk menjalankan aspek "orang" atau sumber daya manusia dari posisi seorang manajemen, meliputi perekrutan, penyaringan, pelatihan, pengimbalan, dan penilaian. Manulang (1987:14 dalam Lasa, 2008: 63) menyatakan bahwa manajemen personalia adalah seni dan ilmu untuk memperoleh, memajukan, dan memanfaatkan tenaga kerja sehingga tujuan organisasi dapat direalisasikan dan sekaligus menimbulkan kegairahan bekerja bagi para pekerja.

Perencanaan sumber daya manusia atau perencanaan tenaga kerja merupakan upaya rekruitmen untuk mendapatkan sumber daya manusia yang cakap, memiliki motivasi tinggi, dan mampu bekerja dengan cermat untuk 
mengintegrasikan berbagai sistem tenaga kerja yang menyeluruh dari suatu organisasi (Lasa, 2008). SDM perpustakaan dapat terdiri atas pejabat fungsional pustakawan, pejabat fungsional lain (dosen, arsiparis, pranata komputer), dan tenaga administrasi. Mereka merupakan pilar utama dalam kegiatan perpustakaan. Maju mundurnya suatu perpustakaan tergantung pada kualitas sumber daya manusia yang terlibat.

Kebutuhan SDM untuk perpustakaan perlu direncanakan dengan mempertimbangkan faktor-faktor jenis kegiatan, kualitas dan kuantitas tenaga, spesialisasi, pemanfaatan teknologi informasi, dana, dan tingkat pendidikan. Oleh karena itu, kebutuhan SDM antara satu perpustakaan dengan perpustakaan yang lain tidak sama. Menurut Lasa Hs. perkembangan perpustakaan perguruan tinggi terlihat lebih nyata dibanding perpustakaan sekolah/ madrasah. Beliau merasa mendengar "tangisan" perpustakaan tersebut. Karena hal ini, Lasa Hs. menyampaikan pemikirannya mengenai SDM perpustakaan sekolah/ madrasah dimungkinkan terdiri guru, pustakawan, tenaga fungsional lain, dan karyawan. Guru berperan sebagai mediator antara perpustakaan-kepala sekolah/ madrasah, perpustakaan-guru, dan perpustakaan-siswa. Pustakawan bertugas untuk melaksanakan kegiatan perpustakaan seperti pengadaan, pencatatan, klasifikasi, pengkatalogan, penjajaran, pengawetan, dan pemberdayaan perpustakaan. Karyawan terdiri dari tenaga administrasi bertugas melaksanakan kegiatan administrasi dan membantu pelaksanaan kegiatan perpustakaan pada umumnya seperti pelabelan, sirkulasi, pembuatan statistik, dan lainnya. Apabila orang yang menangani perpustakaan sekolah belum memenuhi syarat diploma maka disebut sebagai tenaga perpustakaan.

Untuk memacu perkembangan perpustakaan sekolah perlu dibuatkan standar minimal kebutuhan pustakawan (minimal diploma dua perpustakaan), guru pustakawan, dan tenaga administrasi untuk tiap jenjang sekolah. Berikut adalah hasil pemikiran Lasa, Hs yang tertuang dalam Standar Nasional Perpustakaan, antara lain:

1. Perpustakaan Sekolah Dasar/ Madrasah Ibtidaiyah a. Perpustakaan dikelola oleh tenaga perpustakaan sekurang-kurangnya satu orang

b. Apabila perpustakaan sekolah/ madrasah itu memiliki lebih dari enam rombongan belajar, maka sekolah/ madrasah diwajibkan memiliki tenaga perpustakaan sekurang-kurangnya dua orang

c. Kualifikasi tenaga perpustakaan sekolah/ madrasah minimal diploma dua bidang ilmu perpustakaan

d. Gaji tenaga perpustakaan tidak tetap minimal setara dengan upah minimum regional (UMR)

(SNP 007:2011)

2. Perpustakaan sekolah lanjutan pertama/ Madrasah Tsanawiyah

a. Perpustakaan dikelola oleh tenaga perpustakaan sekurang-kurangnya satu orang

b. Apabila perpustakaan sekolah/madrasah itu memiliki lebih dari enam rombongan belajar, maka sekolah diwajibkan memiliki tenaga perpustakaan sekolah sekurang-kurangnya dua orang.

c. Kualifikasi tenaga perpustakaan sekolah/ madrasah minimal diploma dua bidang ilmu perpustakaan

d. Gaji tenaga perpustakaan tidak tetap minimal setara dengan upah minimum regional (UMR)

(SNP 008: 2011)

3. Perpustakaan sekolah lanjutan atas/ Madrasah 'Aliyah

a. Perpustakaan dikelola oleh tenaga perpustakaan sekurang-kurangnya satu orang

b. Apabila perpustakaan sekolah/madrasah itu memiliki lebih dari enam rombongan belajar, maka sekolah diwajibkan memiliki tenaga perpustakaan sekolah sekurang-kurangnya dua orang

c. Kualifikasi tenaga perpustakaan sekolah/ madrasah minimal diploma dua bidang ilmu perpustakaan 
d. Gaji tenaga perpustakaan tidak tetap minimal setara dengan upah minimum regional (UMR)

(SNP 009: 2011)

4. Kepala perpustakaan sekolah/ madrasah akan mendukung kelancaran kegiatan perpustakaan apabila memenuhi syarat antara lain:

a. Kualifikasi kepala perpustakaan sekolah adalah tenaga perpustakaan sekolah atau tenaga kependidikan dengan pendidikan minimal diploma dua di bidang ilmu perpustakaan dan informasi atau diploma dua bidang lain yang sudah memperoleh sertifikat pendidikan di bidang ilmu perpustakaan dan informasi dari lembaga pendidikan terakreditasi

b. Kepala perpustakaan sekolah harus memiliki sertifikat kompetensi perpustakaan yang dikeluarkan oleh lembaga sertifikasi terakreditasi

c. Gaji kepala perpustakaan sekolah minimal setara dengan standar gaji guru sesuai dengan jenjang kepangkatan

(SNP 007, 008, 009:2011)

Agar perpustakaan sekolah lebih maju dan berfungsi optimal, maka diperlukan guru pustakawan. Guru pustakawan adalah guru sekolah yang mendapatkan pendidikan atau pelatihan bidang perpustakaan minimal berbobot 30 SKS. Posisi guru pustakawan sebagai agen perubahan, memengaruhi, dan mengarahkan seluruh komponen sekolah mencapai kualitas pendidikan, dan membentuk lingkungan sekolah yang kondusif untuk melakukan proses belajar. Oleh karena itu, guru pustakawan hendaknya memiliki lima kompetensi. Pertama, kompetensi personal, adalah kompetensi yang harus dimiliki seseorang yang berupa kemampuan individu dalam berkomunikasi dan bekerjasama untuk menciptakan nilai lebih dari penyelenggaraan suatu kegiatan. Kompetensi ini diperoleh melalui pendidikan, pengalamandanbersifatkepribadian. Kedua, kompetensi manajemen, dengan ini guru pustakawan diharapkan antara lain mampu memahami visi, misi, tujuan, dan perencanaan SDM, anggaran, koleksi dan pemberdayaan perpustakaan, memahami koordinasi kegiatan perpustakaan seperti pengolahan, penjajaran, penyimpanan, penyediaan jasa informasi.

Ketiga, kompetensi pendidikan, yakni kemampuan mendorong dan membimbing orang lain (siswa, guru, karyawan) untuk mandiri dalam akses informasi dan pemanfaatan bahan informasi dalam upaya peningkan kualitas diri. Keempat, kompetensi pelayanan, antara lain diharapkan memiliki kompetensi memahami dan memberikan pelayanan yang tepat kepada guru dan siswa sesuai tujuan pembelajaran. Selanjutnya kompetensi ilmu pengetahuan, perpustakaan sebagai sumber ilmu pengetahuan harus dikelola dengan ilmu perpustakaan dan ilmu-ilmu lain yang terkait seperti ilmu informasi, manajemen, statistik, komputer, psikologi, komunikasi, dan lainnya.

Untuk memperoleh SDM yang berkualitas perludilakukan perekrutansecaraterbuka, selektif, objektif dan memenuhi standar kompetensi. Artinya untuk pustakawan seharusnya memiliki pendidikan formal minimal diploma dua bidang ilmu perpustakaan, dokumentasi, dan informasi. Di samping itu, mereka juga harus memiliki kemampuan manajerial, kemandirian, inovatif, dinamis dan mampu bekerja sama. Pemikiran ini sesuai dengan PP RI no. 24 tahun 2014 Ps. 34 (1) disebutkan bahwa pustakawan harus memiliki kompetensi profesional dan kompetensi personal. Perekrutan dapat dilakukan dengan penjaringan melalui tes, pengangkatan orang dalam, pengangkatan orang yang pernah magang, dan mutasi.

Penempatan pegawai harus disesuaikan dengan kriteria perekrutan semula tentang pendidikan, keahlian, pengalaman, dan kemampuan mereka. Penempatan yang kurang sesuai akan berakibat manajemen kurang efektif dan kurang efisien. SDM yang telah ada hendaknya selalu dikembangkan dengan pendidikan, pelatihan dan magang. Kompensasi perlu diberikan kepada pegawai dengan maksud mengikat, mempertahankan, memotivasi, dan memenuhi peraturan yang berlaku. Kompensasi langsung dapat berupa tunjangan isteri, tunjangan anak, tunjangan hari raya, dan lainnya. Kompensasi tidak langsung dapat berupa asuransi kesehatan, jaminan hari tua, dan lainnya. Selain kompensasi SDM harus diberikan imbalan sebagai konsekuensi logis dari pelaksanaan tugas, kewajiban, dan wewenang. Apabila dari segi keuangan belum memungkinkan untuk mengangkat pustakawan secara fulltime, 
kiranya dapat ditempuh dengan pengangkatan model paruh waktu. Dengan demikian seorang pustakawan dalam satu minggu dapat menangani beberapa perpustakaan sekolah. Dengan cara ini, perpustakaan sekolah semakin lama akan tertata sesuai ilmu perpustakaan.

Agar pelaksanaan tugas dan kewajiban dapat lancar perlu adanya perlindungan dan hak dalam bentuk keselamatan kerja, kesehatan kerja dan kesejahteraan pegawai. Dalam upaya penciptaan keselamatan kerja perlu diperhatikan tentang prinsip keselamatan, antara lain: mencegah dan mengurangi kecelakaan seperti kebakaran, peledakan, dan reruntuhan; memelihara kebersihan, kesehatan, dan ketertiban. Selanjutnya dalam lingkungan kerja perlu dicegah jangan sampai terjadi stress, penekanan, sakit mental dan lainnya yang menyebabkan menurunnya kinerja karyawan. Penurunan kinerja berarti mengurangi produktivitas lembaga. Dalam hal ini perlu adanya pembinaan agama dan moral bagi mereka. Selain gaji, kesejahteraan pegawai perlu diperhatikan. Mereka memerlukan rekreasi, bonus, simpan pinjam, dan lainnya. Hal semacam ini besar pengaruhnya terhadap kinerja karyawan.

\section{Analisis Pemikiran Lasa Harsana tentang Manajemen Sumber Daya Manusia}

a. Analisis Pemikiran

Pemikiran Lasa Hs menempatkan sumber daya manusia merupakan pilar utama dalam kegiatan perpustakaan. Maju mundurnya suatu perpustakaan tergantung pada kualitas sumber daya manusia yang terlibat. Hal ini sesuai dengan pernyataan Wakil Presiden dari Sumber Daya Manusia pada Toyota Motor Manufacturing di Georgetown, Kentucy dalam Dessler (1997) "orang berada dibalik sukses".

Syarat kompetensi untuk menjadi pustakawan, selain kompetensi profesi dan kompetensi personal sesuai yang diamanahkan Undang-Undang Nomor 43 Tahun 2007 tentang perpustakaan, Lasa Hs menambahkan untuk menjadi SDM yang berkualitas, seseorang harus memiliki kompetensi manajemen dan kompetensi pelayanan. Untuk mencapai tujuan organisasi perlu dilakukan perekrutan secara terbuka, selektif, dan objektif. Penempatan pegawai harus disesuaikan dengan kriteria perekrutan semula tentang pendidikan, keahlian, pengalaman, dan kemampuan mereka. Selanjutnya SDM yang telah ada hendaknya selalu dikembangkan dengan pendidikan, pelatihan, dan magang. Dari pemaparan tersebut terlihat fungsi manajemen sumber daya manusia menurut Lasa, Hs. yakni mencakup penyediaan staf, pengembangan sumber daya manusia, kompensasi, keselamatan dan kesehatan. Hal ini mendukung pernyataan Mondy (2008).

Lasa Hs., mempunyai pemikiran ke depan mengenai sumber daya manusia perpustakaan, hal ini terlihat dari harapannya terhadap standar kompetensi pustakawan yaitu adanya kompetensi khusus. Kompetensi khusus hanya bisa diwujudkan dengan adanya dukungan kurikulum dalam pendidikan kepustakawanan. Kedepannya kompetensi khusus ini menjadi "pustakawan spesialis", contohnya pustakawan dengan kemampuan Arab Gundul seperti halnya dokter spesialis mata, dan seterusnya. Dalam mewujudkan pemikiran ini perlu dukungan kurikulum, diperlukan semacam pendidikan profesi sebagai kelanjutan pendidikan strata satu ilmu perpustakaan (seperti halnya syarat pendidikan profesi lain: dokter, notaris, perawat, dan seterusnya). Setelah selesai pendidikan strata satu untuk menjadi seorang perawat diharuskan mengikuti pendidikan profesi, hal ini hendaknya bisa diterapkan dalam bidang kepustakawanan.

Selanjutnya untuk menjamin kualitas pustakawan, hendaknya ada peninjauan ulang mengenaikebijakan yang menimbulkan adanya pustakawan "abu-abu" yakni pustakawan yang berpendidikan D2, D3, ataupun $\mathrm{S} 1$ bukan ilmu perpustakaan namun memiliki gelar Magister IImu Perpustakaan. Peninjauan ulang juga perlu dilakukan pada model pendidikan penyetaraan. Dimana seorang yang memiliki Diploma atau Sarjana S1 bidang lain lalu mengikuti pendidikan dan pelatihan perpustakaan selama sekian bulan, lalu mereka disetarakan dengan Iulusan 
Sumber Daya Manusia Dalam ... (Anisa Sri Restanti)

Diploma atau Sarjana ilmu perpustakaan dan mereka diangkat sebagai pustakawan.

Demikian pula dengan model sertifikasi Kepala Perpustakaan Sekolah yang hanya melalui pelatihan sekian hari, lalu mereka diangkat sebagai kepala perpustakaan sekolah. Hal ini jelas bertentangan dengan peraturan pemerintah tersebut dan ini merupakan penggusuran profesi pustakawan.

b. Kontribusi pemikiran Lasa Hs bagi Dunia Kepustakawanan

Adapun kontribusi pemikiran Lasa Hs bagi dunia kepustakawanan, antara lain:

- Lasa Hs telah mencurahkan pemikirannya melalui tulisan yang dapat digunakan sebagai referensi yang tentu saja bermanfaat bagi perkembangan kepustakawanan di Indonesia, yang salah satu kasil karya bidang kepustakawanan adalah Kamus Istilah Perpustakaan yang menjadi trademark Lasa Hs. dan kini terus direvisi

- Berperan serta dalam penyusunan Standar Nasional Perpustakaan Sekolah.

- Megembangkan profesi pustakawan dengan menjadi Tim Penilai Jabatan Fungsional Pustakawan, menjadi pengurus organisasi kepustakawanan, dan lainnya

- Berperan dalam pengembangan pendidikan formal dan nonformal bidang perpustakaan di Yogyakarta, seperti Diklat Papustak Gama (dirintis oleh Ibu Sawittri-Soeharto), ikut berperan serta lahirnya Diploma Ilmu Perpustakaan Fakultas Adab UIN Sunan Kalijaga, mengajar, sebagai tutor dll.

- Membina dan mengembangkan penulisan kepustakawanan antara lain menjadi redaksi berbagai terbitan kepustakawanan, dan memotivasi pustakawan, mahasiswa ilmu perpustakaan, dan petugas perpustakaan untuk menulis dan menulis di bidang kepustakawanan atau bidang lain.

c. Harapan Lasa Hs terhadap Dunia Kepustakawanan
Harapan Lasa Hs terhadap dunia kepustakawanan, antara lain:

- Setelah perkembangan teknologi saat ini, telah banyak pula pustakawan berpendidikan S1 maupun S2, bahkan Iulusan luar negeri, beliau berharap generasi ini lebih produktif dalam menulis karya tulis sehingga citra pustakawan semakin baik di mata masyarakat.

- Harapan bagi universitas penyelenggara pendidikan formal ilmu perpustakaan dan informasi untuk bisa melahirkan pustakawan berkompetensi khusus. Misalnya pustakawan perpustakaan Islam dengan kemampuan Arab gundul. Saat ini terjadi kendala dalam pengolahan koleksi dengan tulisan Arab gundul. Harapan kedepannya kompetensikhusus ini menjadi "pustakawan spesialis". Seperti halnya dokter spesialis mata, dan seterusnya.

- Secara pribadi Lasa Hs berharap untuk terus berkaryauntukmemberikan manfaat yang lebih luas bagi kepustakawanan.

\section{Kesimpulan}

Pemikiran Lasa Harsana dalam mendefinisikan manajemen, Lasa Hs menekankan pada kegiatan manajemen didukung oleh pemikiran Sutarno NS. Sementara itu pemikiran Lasa Hs berbeda dengan definisi manajemen yang disampaikan oleh Abdul Rahman Saleh. Lasa Hs menempatkan sumber daya manusia merupakan pilar utama dalam kegiatan perpustakaan. Hal ini sesuai dengan pernyataan Wakil Presiden dari Sumber Daya Manusia pada Toyota Motor Manufacturing di Georgetown, Kentucy dalam Dessler, 1997 "orang berada dibalik sukses". Fungsi manajemen sumber daya manusia menurut Lasa, Hs, yakni mencakup penyediaan staf, pengembangan sumber daya manusia, kompensasi, keselamatan dan kesehatan. Hal ini mendukung pernyataan Mondy, (2008). Selanjutnya, peningkatan sumber daya manusia (SDM) perlu mendapat perhatian utama karena sumber daya ini merupakan sumber bergerak, sedangkan sumber daya lain merupakan benda mati. Oleh karena itu, sumber daya manusia 
ini dapat dikembangkan dan ditingkatkan kemampuannya, yang hasilnya diharapkan mampu meningkatkan produktivitas dan kinerja perpustakaan.

\section{Daftar Pustaka}

Chon, John M. dan Ann L. Kelsey. 2005. Staffing the modern library : a how-to-do-it manual. New York: Neal-Schuman Publisers

Dessler, Gary. 1997. Manajemen Sumber Daya Manusia. Jakarta: Prenhallindo

Hartinah, Sri. 2013. Materi Pokok Metode Penelitian Perpustakaan. Tangerang Selatan: Universitas Terbuka

Indonesia. Undang-Undang no. 43 tahun 2007 tentang Perpustakaan

Lasa Hs. 2008. Manajemen Perpustakaan. Yogyakarta: Gama Media

--------. 2009. Manajemen Perpustakaan Sekolah. Yogyakarta: Pinus

--------2013. Manajemen Perpustakaan Sekolah/ Madrasah Revisi. Yogyakarta: Ombak

--------. 2009. Kamus Kepustakawanan Indonesia. Yogyakarta: Pustaka Publ.Book.

Moleong, Lexi J. 2007. Metodologi Penelitian Kualitatif edisi revisi. Bandung: Remaja Rosdakarya

Mondy, R.Wayne. 2008. Manajemen Sumber Daya Manusia. Jakarta: Erlangga

Pendit, Putu Laxman. 2003. Penelitian IImu Perpustakaan dan Informasi:suatu pengantar diskusi epistimologi dan metodologi. Jakarta: JIP-FSUI

Saleh, Abdul Rahman dan Rita Komalasari. 2011. Materi Pokok Manajemen Perpustakaan. Jakarta: Universitas Terbuka

Sulistyo-Basuki. 1991. Pengantar IImu Perpustakaan. Jakarta: Gramedia

Sutarno NS. 2006. Manajemen Perpustakaan. Jakarta: Sagung Seto

Qalyubi, Syihabuddin. 2003. Dasar-dasar IImu Perpustakaan dan Informasi. Yogyakarta: Fak. Adab jurusan IImu Perpustakaan dan Informasi 